\title{
PENERAPAN AKUNTANSI KEUANGAN DAERAH PENERAPAN AKUNTANSI KEUANGAN DAERAT
DALAM MENINGKATKAN TRANSPARANSI DAN AKUNTABILITAS
LAPORAN KEUANGAN DI PROVINSI JAWA BARAT
}

\author{
Oleh : \\ Ikin Solikin \\ (Dosen Program Studi Akuntansi Fakultas Pendidikan Ekonomi \& Bisnis UPI)
}

\begin{abstract}
Abstrak
Penelitian ini bertujuan untuk mengetahui Penerapan Akuntansi Keuangan Daerah, Transparansi dan Akuntabilitas Laporan Keuangan serta bagaimana Penerapan Akuntansi Keuangan Daerah dapat meningkatkan Transparansi dan Akuntabilitas Laporan Keuangan di Provinsi Jawa Barat. Penelitian ini menggunakan metode analisis deskriptif yaitu metode penelitian yang tertujuan pada pemecahan masalah-masalah yang ada pada masa sekarang. Dalam penelitian ini yang menjadi populasi adalah para personil Biro Keuangan SETDA Provinsi Jawa Barat. Teknik sampling yang digunakan adalah sampling proporsional. Untuk menunjang keberhasilan penelitian ini, penyusun mengumpulkan data dengan menyebarkan kuesioner, selain itu juga melakukan observasi lapangan dan wawancara dengan pegawai Biro Keuangan khususnya pada bagian Akuntansi dan Pelaporan. Berdasarkan hasil penelitian diketahui bahwa Penerapan Akuntansi Keuangan Daerah Pemerintah Provinsi Jawa Barat menunjukkan kondisi yang sangat baik sedangkan Transparansi dan Akuntabilitas Laporan Keuangan Pemerintah Provinsi Jawa Barat berada pada kategori baik. Dari hasil penelitian ini juga menunjukkan berbanding lurusnya antara penerapan akuntansi keuangan daerah yang sangat baik dengan baiknya transparansi dan akuntabilitas laporan keuangan Pemerintah Provinsi Jawa Barat.
\end{abstract}

Kata kunci : Akuntansi Keuangan Daerah, Transparansi, Akuntabilitas.

\section{Latar Belakang}

Tata kelola yang baik (good governance) merupakan issue yang paling mengemuka dalam pengelolaan administrasi publik dewasa ini. Tuntutan gencar yang dilakukan oleh masyarakat kepada pemerintah untuk melaksanakan penyelenggaraan pemerintahan yang baik adalah sejalan dengan meningkatnya tingkat pengetahuan masyarakat. Pola-pola lama penyelenggaraan pemerintahan tidak sesuai lagi bagi tatanan masyarakat yang telah berubah. Oleh karena itu, tuntutan itu merupakan hal yang wajar dan sudah seharusnya direspon oleh pemerintah dengan melakukan perubahan-perubahan yang terarah pada terwujudnya penyelenggaraan pemerintahan yang baik.

Pemerintah harus melakukan reformasi ke seluruh aspek kehidupan, salah satu aspek reformasi yang dominan adalah aspek pemerintahan. Aspek pemerintahan yaitu aspek hubungan pemerintah pusat dengan daerah. Pada aspek ini isu yang mencuat adalah adanya tuntutan otonomi yang lebih luas dan nyata yang harus diberikan pemerintah pusat kepada pemerintah kabupaten atau kota.

Tuntutan reformasi yang didukung oleh sebagian besar masyarakat Indonesia dalam menyikapi berbagai permasalahan di daerah akhir-akhir ini, membawa dampak terhadap peningkatan mutu pelayanan publik. Hal ini dipicu oleh pengalaman sistem pemerintahan yang lalu, yang kurang memperhatikan kepentingan masyarakat, tetapi cenderung menguntungkan pihak yang berkuasa. Akibatnya timbul berbagai masalah sosial seperti korupsi, kolusi, dan nepotisme yang sulit diberantas, belum berjalannya proses penegakan hukum, kualitas pelayanan kepada masyarakat yang memburuk serta 
masalah perimbangan keuangan antara pemerintah pusat dan pemerintah daerah yang dinilai tidak adil. Oleh karena itu, sistem pengelolaan keuangan daerah yang baik diperlukan untuk mengelola dana desentralisasi secara transparan, ekonomis, efisien, efektif dan akuntabel.

Pelaksanaan otonomi daerah sistem pengelolaan keuangan daerah yang baik difokuskan untuk mengelola dana secara desentralisasi dengan transparan, efisien, efektif, dan dapat dipertanggungjawabkan kepada masyarakat luas. Penyusunan laporan keuangan dengan menggunakan sistem akuntansi keuangan daerah diharapkan mampu mewujudkan tercapainya transparansi dan akuntabilitas.

Upaya perbaikan di bidang pengelolaan keuangan daerah ini nampaknya belum dapat dilaksanakan sepenuhnya oleh pemerintah daerah, pada kenyataannya banyak pemerintah daerah yang belum dapat menyusun Laporan Keuangan tersebut, terutama hal ini disebabkan oleh berbagai hal yaitu selain berupa peraturan yang saling bertentangan yang dikeluarkan oleh Departemen di tingkat nasional, kesulitan juga berasal dari siklus keuangan pemerintah daerah. Mulai dari pengesahan anggaran sampai ke penyusunan laporan keuangan, yang disebabkan oleh kompleksitas peraturan, kurangnya SDM, buruknya koordinasi dan tidak memadainya teknologi yang digunakan. Selain itu masalah publikasi Laporan Keuangan oleh Pemerintah Daerah (melalui surat kabar, internet, atau dengan cara lainnya) yang nampaknya belum menjadi hal yang umum.

Penyajian Laporan Keuangan Pemerintah Provinsi Jawa Barat sebenarnya sudah dianggap mampu melaksanakannya, hal ini terbukti dengan terbitnya Laporan Keuangan Pemerintah Daerah pada tahun anggaran 2006 dan 2007. Penyusunan Laporan Keuangan Pemerintah Provinsi Jawa Barat TA 2007 sudah mulai menerapkan sistem pembukuan double entry disajikan sesuai dengan Permendagri Nomor 13 Tahun 2006 tentang Pedoman Pengelolaan Keuangan Daerah, lalu bentuk dan susunan dikonversi sesuai dengan Standar Akuntansi Pemerintahan (SAP). Namun hasil Pemeriksaan Laporan Keuangan Pemerintah Daerah yang diterbitkan oleh BPK RI Perwakilan Jawa Barat, masih menemukan bahwa Pemerintah Provinsi Jawa Barat masih belum memahami sepenuhnya mengenai sistem pencatatan dengan double entry dan dasar pencatatan accrual basis.

\section{Rumusan Masalah}

Berdasarkan uraian diatas maka, rumusan masalah adalah sebagai berikut:

1. Bagaimana penerapan akuntansi keuangan daerah,

2. Bagaimana Transparansi dan Akuntabilitas Laporan Keuangan

3. Bagaimana Penerapan Akuntansi Keuangan Daerah dalam rangka meningkatkan Transparansi dan Akuntabilitas Laporan Keuangan Pemerintah Provinsi Jawa Barat.

\section{Kerangka Pemikiran}

Setelah hampir sepuluh tahun berlakunya otonomi daerah hampir belum ada kemajuan signifikan yang ditunjukan oleh pemerintah daerah. Laporan Keuangan Pemerintah Daerah (LKPD) dalam tiga tahun terakhir secara umum masih buruk (siaran pers, BPK RI, 23 Juni 2008).

Laporan keuangan pemerintah daerah sebagai bentuk pertanggungjawaban pelaksanaan APBD harus disusun atau dihasilkan dari sebuah sistem akuntansi pemerintah daerah yang handal, yang bisa dikerjakan secara manual ataupun menggunakan aplikasi komputer. Namun mengingat sumber daya manusia yang masih sangat minim yang berspesialisasi di bidang akuntansi khususnya akuntansi keuangan sektor publik maka akan lebih tepat jika menggunakan sistem aplikasi komputer yang komprehensif dan sudah teruji. Hal ini akan dapat meminimalkan kesalahan proses akuntansi dan meningkatkan kualitas laporan keuangan yang dihasilkan. 
Pada hakekatnya di dalam pemerintahan daerah belum dapat menyusun laporan keuangan dan belum memahami sistem akuntansi. Sedangkan berdasarkan Peraturan Pemerintah No. 24 tahun 2005 tentang Standar Akuntansi Pemerintahan (SAP) menyatakan bahwa pemerintah menyusun sistem akuntansi pemerintahan yang mengacu pada SAP. Sistem akuntansi pemerintahan pada tingkat pemerintah pusat diatur dengan Peraturan Menteri Keuangan. Sistem akuntansi pemerintahan pada tingkat pemerintah daerah diatur dengan peraturan gubernur / bupati / walikota, mengacu pada Peraturan Daerah tentang pengelolaan keuangan daerah yang berpedoman pada Peraturan Pemerintah.

Mardiasmo (2004 : 35) mengatakan bahwa untuk dapat menghasilkan laporan keuangan yang relevan, handal dan dapat dipercaya, pemerintah daerah harus memiliki sistem akuntansi yang handal. Sistem akuntansi yang lemah menyebabkan laporan keuangan yang dihasilkan juga kurang handal dan kurang relevan untuk pembuatan keputusan. Saat ini sistem akuntansi yang dimiliki pemerintah daerah rata-rata masih lemah.

Permendagri No. 13 tahun 2006 tentang Pedoman Pengelolaan Keuangan Daerah Pasal 232 mengatakan bahwa sistem akuntansi pemerintahan daerah adalah : "serangkaian prosedur mulai dari proses pengumpulan data, pencatatan, pengikhtisaran, sampai dengan pelaporan keuangan dalam rangka pertanggungjawaban pelaksanaan APBD yang dapat dilakukan secara manual atau menggunakan aplikasi komputer."

Dalam rangka pertanggungjawaban pelaksanaan APBD, setiap SKPD menyusun dan melaporkan pertanggungjawaban pelaksanaan APBD tersebut secara periodik yang meliputi : Laporan Realisasi Anggaran SKPD, Neraca SKPD, Catatan atas Laporan keuangan SKPD

Sistem akuntansi pemerintahan daerah dilaksanakan oleh Pejabat Pengelola Keuangan Daerah (PPKD), sedangkan sistem akuntansi Satuan Kerja Perangkat Dinas (SKPD) dilakukan oleh PPK-SKPD.

Pemerintah, baik pusat maupun daerah harus bisa menjadi subyek pemberi informasi dalam rangka pemenuhan hak-hak publik, yaitu hak untuk mengetahui (right to know), hak untuk diberi informasi (right to be informed) dan hak untuk didengar aspirasinya (right to be heard and to be listened to). Hal ini semua pada akhimya menuntut kemampuan aparatur pemerintah daerah dalam menghasilkan laporan keuangan yang berkualitas.

Karakteristik kualitatif laporan keuangan menurut PP No. 24 tahun 2005 tentang Standar Akuntansi Pemerintahan (SAP) adalah ukuran-ukuran normatif yang perlu diwujudkan dalam informasi akuntansi sehingga dapat memenuhi tujuannya. Keempat karakteristik berikut ini merupakan prasyarat normatif yang diperlukan agar laporan keuangan pemerintah daerah dapat memenuhi kualitas yang dikehendaki yaitu Relevan, Andal, Dapat Dibandingkan dan Dapat Dipahami. Penelitian yang dilakukan oleh Erwin Danismaya (2009) dengan judul "Pengaruh Penerapan Sistem Akuntansi Keuangan terhadap Akuntabilitas Laporan Keuangan pada Pusat Pengembangan dan Pemberdayaan Pendidik dan Tenaga Kependidikan Bandung", menyatakan terdapat hubungan yang positif sebesar 52,8\% antara Sistem Akuntansi Keuangan terhadap Akuntabilitas Laporan Keuangan.

Dari pemaparan di atas berpijak pada teori-teori yang ada bahwa pemerintah daerah menyusun sistem akuntansi yang mengacu pada SAP guna menghasilkan laporan keuangan pemerintah daerah sesuai dengan SAP dan juga dengan adanya sistem akuntansi yang handal akan menghasilkan kualitas laporan keuangan.

\section{Metode Penelitian}

Pada penelitian yang penulis lakukan ini, metode yang digunakan adalah metode deskriptif analitik, yaitu suatu metode yang menggambarkan keadaan yang sebenarnya 
berdasarkan data yang ada, kemudian data yang diperoleh selama penelitian diolah, dianalisis dan diproses lebih lanjut berdasarkan teori-teori yang telah dipelajari, dan dijadikan sebagai bahan pembahasan untuk menentukan hubungan, pengaruh, serta keterkaitan antara variabel-variabel yang diteliti.

Dalam penelitian ini, teknik pengumpulan data dilakukan dengan menggunakan data primer, yaitu data yang diperoleh secara langsung yang memiliki hubungan yang relevan dengan penelitian yang dilakukan. Data tersebut diperoleh dari hasil penyebaran kuesioner kepada responden.

Alat ukur yang digunakan untuk mengumpulkan data dalam penelitian ini adalah skala Likert dengan menggunakan variabel berukuran interval, karena kuesioner berupa pilihan berganda dengan lima alternatif jawaban yang bertujuan untuk mengukur sikap, pendapat maupun persepsi seseorang.

\section{Hasil Penelitian}

\section{Penerapan Akuntansi Keuangan Daerah}

Pengumpulan data untuk variabel X diperoleh dari penyebaran angket kepada 57 responden yang terdiri dari 14 pertanyaan dan dibagi ke dalam indikator. Untuk mengetahui gambaran mengenai variabel $\mathrm{X}$, berikut ini disajikan tanggapan responden terhadap pertanyaan yang diuraikan per indikator.

Secara umum, gambaran variabel $\mathrm{X}$ secara keseluruhan pada Biro Keuangan SETDA Pemerintah Provinsi Jawa Barat dapat dilihat pada tabel rekapitulasi rata-rata jawaban untuk masing-masing indikator di bawah ini :

Tabel 1.1

Rekapitulasi Rata-Rata Jawaban

Variabel Penerapan Akuntansi Keuangan Daerah

\begin{tabular}{|c|l|c|}
\hline No. & \multicolumn{1}{|c|}{ Penerapan Akuntansi Keuangan Daerah } & Persentase (\%) \\
\hline 1. & Indikator Adanya Ketepatan Waktu & 86,3 \\
\hline 2. & Indikator Adanya Penjurnalan & 75,4 \\
\hline 3. & Indikator Dokumen dan Catatan/Bukti Tertulis pada saat Pemakaian Fasilitas & 85,9 \\
\hline 4. & & \\
\hline 5. & Indikator Adanya Metode Pencatatan Mempermudah Kinerja & 88,7 \\
\hline 6. & $\begin{array}{l}\text { Indikator Adanya Posting Ke Buku Besar sesuai dengan Nomor Perkiraan/Kode- } \\
\text { Kode Akun }\end{array}$ & 84,2 \\
\hline 7. & Indikator Perlunya Buku Pembantu pada Prosedur Pencatatan & 85,9 \\
\hline 8. & Indikator Adanya Periode Penyusunan Laporan Keuangan & 73,6 \\
\hline 9. & $\begin{array}{l}\text { Indikator Adanya Laporan Keuangan Yang Dihasilkan terdiri dari Laporan } \\
\text { Realisasi Anggaran, Laporan Neraca, Laporan Arus Kas, Catatan Atas Laporan } \\
\text { Keuangan }\end{array}$ & 84,9 \\
\hline 10. & Indikator Adanya Ketepatan Waktu Laporan yang dibuat & 95,0 \\
\hline 11. & Indikator Adanya Keakuratan Laporan Keuangan & 71,9 \\
\hline 12 & Indikator Laporan yang dibuat Membantu Pengambilan Keputusan & 81,7 \\
\hline 13 & Indikator Adanya Perbandingan antara Periode Berjalan dan Sebelumnya & 82,1 \\
\hline 14 & Indikator Adanya Evaluasi Terhadap Akuntansi Keuangan Daerah & 90,1 \\
\hline & & 80,3 \\
\hline
\end{tabular}

Sumber: Data primer yang telah diolah

Untuk mengetahui besarnya rata-rata persentase dari penerapan akuntansi keuangan daerah seluruhnya maka dapat dicari dengan menggunakan rumus:

$$
\bar{x}=\frac{\sum x_{i}}{n}=\frac{1.166 \%}{14}=83,28 \%
$$

Berdasarkan perhitungan di atas diperoleh rata-rata untuk variabel $\mathrm{X}$ yaitu sebesar 83,28\%. Hal berarti Penerapan Akuntansi Keuangan Daerah termasuk dalam kriteria sangat baik yaitu berkisar antara $81 \%-100 \%$. 
Berdasarkan hasil pengumpulan data dan penilaian responden menunjukkan bahwa pemahaman tentang Akuntansi Keuangan Daerah dari para personil Biro Keuangan SETDA Provinsi Jawa Barat, secara umum mengetahui tentang Akuntansi Keuangan Daerah, akan tetapi masih terlihat beberapa yang belum memahami dengan benar mengenai Akuntansi Keuangan Daerah. Penilaian responden terhadap Akuntansi Keuangan Daerah pada Biro Keuangan SETDA Provinsi Jawa Barat nilai yang diperoleh adalah sebesar $83,28 \%$ yang termasuk ke dalam kategori sangat baik. Dengan demikian maka dapat dikatakan tingkat pemahaman para personil Biro Keuangan SETDA Provinsi Jawa Barat sudah sangat baik. Hal ini dapat dilihat dari beberapa indikator :

a) Biro Keuangan SETDA Provinsi Jawa Barat sudah dapat menyelenggarakan akuntansi sesuai dengan peraturan yang berlaku berdasarkan Permendagri No. 59 Tahun 2007 tentang Pedoman Pengelolaan Keuangan Daerah dan sebagian besar sudah sesuai dengan Peraturan Pemerintah No. 24 Tahun 2005 Tentang Standar Akuntansi Pemerintah (SAP).

b) Sudah menggunakan aturan-aturan akuntansi yang sudah ditetapkan dalam peraturan pemerintah seperti menggunakan sistem pencatatan double entry dan penggunaan metode accrual basis dalam pengakuan harta, utang, modal dan cash basis dalam pengakuan pendapatan dan biaya.

c) Kegiatan penyelenggaraan akuntansi (siklus akuntansi) sudah dikatakan lengkap karena semua sudah dilakukan mulai dari kegiatan pengumpulan bukti-bukti transaksi, pencatatan atau menjurnal, kemudian posting ke buku besar sampai kepada pembuatan laporan keuangan yang sesuai dengan prinsip-prinsip akuntansi secara umum. Periode pelaporan yang disusun oleh Biro Keuangan SETDA Provinsi Jawa Barat sudah sangat sesuai dengan Peraturan Standar Akuntansi Pemerintahan (SAP), minimal sekali dalam setahun laporan tersebut selalu disajikan tepat waktu. Ketepatan waktu selalu diperhatikan dalam setiap pelaporannya, kalaupun terjadi keterlambatan itu disebabkan oleh SKPD yang terlambat melaporkan kepada Biro Keuangan SETDA Provinsi Jawa Barat.

Untuk meningkatkan kualitas pengelolaan keuangan daerah dan pemahaman pegawainya dalam bidang akuntansi, Pemerintah Provinsi Jawa Barat masih menghadapi beberapa kendala dalam pelaksanaanya, diantaranya adalah :

a) Sebagian besar Sumber Daya Manusia (SDM) yang ada, dan para pegawai penata pelaksana keuangannya banyak yang tidak mempunyai basic bidang akuntansi sehingga dalam pelaksanaan banyak yang kurang bisa menyerap dengan cepat materi pelatihan yang penuh dengan teknik-teknik ilmu akuntansi.

b) Banyak staf sub bagian keuangan yang tidak berkeinginan untuk sungguh-sungguh memahami berbagai peraturan tentang pengelolaan keuangan daerah, atau melaksanakannya dengan terpaksa. Alasannya karena peraturan-peraturan yang ada pada pemerintahan itu penuh dengan ilmu akuntansi yang sangat sulit dipahami oleh mereka.

c) Banyaknya perangkat hukum atas peraturan yang dikeluarkan oleh pemerintah pusat yang tidak sinkron dan tumpang tindih antara satu peraturan dengan peraturan lainnya. Selain itu ketika satu peraturan baru juga dilaksanakan tetapi ternyata sudah dinyatakan tidak berlaku lagi dan kemudian digantikan oleh peraturan yang lain. Kondisi yang seperti ini sering kali membingungkan Pemerintah Daerah.

\section{Transparansi dan Akuntabilitas Laporan Keuangan}

Sama halnya dengan variabel $\mathrm{X}$, pengumpulan data untuk variabel $\mathrm{Y}$ pun diperoleh dari penyebaran angket kepada 57 responden yang terdiri dari 15 pertanyaan dan dibagi ke dalam 10 indikator. Berikut ini disajikan tanggapan responden terhadap pertanyaan terhadap variabel $\mathrm{Y}$ yang diuraikan per indikator. 
Secara umum, gambaran variabel $Y$ secara keseluruhan pada Biro Keuangan SETDA Pemerintah Provinsi Jawa Barat dapat dilihat pada tabel rekapitulasi rata-rata jawaban untuk masing-masing indikator di bawah ini :

Tabel 1.2

Rekapitulasi Rata-Rata Jawaban Untuk Variabel Y

\begin{tabular}{|c|c|c|}
\hline No. & Penerapan Akuntansi Keuangan Daerah & Persentase (\%) \\
\hline 1. & $\begin{array}{l}\text { Indikator Adanya Ketersediaan Informasi Bagi Publik Mengenai } \\
\text { Kepemerintahan }\end{array}$ & 77,5 \\
\hline 2. & Indikator Adanya Laporan Pertanggungjawaban Unit Kerja Secara Periodik & 79,6 \\
\hline 3. & $\begin{array}{l}\text { Indikator adanya Kejelasan Tugas Dan Wewenang Dalam Struktur Organisasi } \\
\text { Kepemerintahan }\end{array}$ & 76,1 \\
\hline 4. & Indikator Adanya Sistem Anggaran Yang Terbuka & 67,3 \\
\hline 5. & $\begin{array}{l}\text { Indikator Adanya lembaga independen yang mengawasi seluruh proses } \\
\text { kepemerintahan }\end{array}$ & 72,0 \\
\hline 6. & Indikator Adanya Pengunkapan Laporan Keuangan Secara Jelas & 78,0 \\
\hline 7. & Indikator Kesiapan Pemeriksaan Mendadak & 81,0 \\
\hline 8. & $\begin{array}{l}\text { Indikator Melaporkan Seluruh Kegiatan Administrasi Kepada Masyarakat } \\
\text { Secara Periodik }\end{array}$ & 68,7 \\
\hline 9. & Indikator Adanya Pertanggungjawaban Pimpinan Terhadap Unit Kerja & 73,6 \\
\hline 10. & Indikator Adanya Kesiapan Memberikan Laporan Unit Kerja Jika Diperlukan & 80 \\
\hline & Jumlah & 753,8 \\
\hline
\end{tabular}

Sumber: Data primer yang telah diolah

Untuk mengetahui besarnya rata-rata persentase dari penerapan akuntansi keuangan daerah seluruhnya maka dapat dicari dengan menggunakan rumus:

$$
\bar{x}=\frac{\sum x_{i}}{n}=\frac{753,8 \%}{10}=75,38 \%
$$

Berdasarkan perhitungan di atas diperoleh rata-rata untuk variabel $\mathrm{Y}$ adalah sebesar 75,38\%, termasuk dalam kriteria baik yaitu berkisar antara $61 \%-80 \%$.

Berdasarkan hasil pengumpulan data dan penilaian responden menunjukkan bahwa para personil Biro Keuangan SETDA Provinsi Jawa Barat, secara umum mengetahui tentang Transparansi dan Akuntabilitas Laporan Keuangan dan nilai yang diperoleh adalah sebesar 75,38\% yang termasuk ke dalam kategori tingkatan baik.

Adapun beberapa hasil perhitungan dan wawancara untuk pelaksanaan transparansi dan akuntabilitas laporan keuangan adalah pertama kejelasan tugas pokok dan wewenang. Dari jawaban responden dihasilkan skor $76,1 \%$ berada pada tingkat kategori baik. Kondisi tersebut menggambarkan bahwa sudah ada pelaksanaan prinsipprinsip transparansi dan akuntabilitas pada laporan keuangan pemerintah Provinsi Jawa Barat walaupun tidak sangat baik.

Pertama pembagian tugas dan wewenang dilakukan dengan baik sehingga fungsi dan wewenang dengan posisi jabatan yang diemban sudah terlaksana dengan baik. Begitu pula dengan garis komando yang berlaku dalam struktur organisasi sudah dapat berjalan dengan baik sehingga alur birokrasi berjalan lancar.

Kedua yaitu ketersediaan sistem informasi bagi publik. Hasil perhitungan terhadap jawaban responden sebesar $77,5 \%$. Nilai tersebut masuk ke dalam tingkat kategori baik atau kuat. Dalam pelaksanaannya instansi-instansi pemerintah khususnya Biro Keuangan SETDA memberikan kemudahan bagi masyarakat untuk mengakses informasi, namun karena adanya keterbatasan media informasi yang digunakan menjadikan setiap laporan ataupun informasi yang tersaji bersifat ekslusif atau hanya bisa diakses oleh golongan tertentu saja. 
Ketiga berupa sistem anggaran yang terbuka bagi masyarakat. Sistem anggaran yang terbuka merupakan salah satu indikator dari transparansi dan akuntabilitas. Dari hasil perhitungan jawaban responden di dapat skor $67,3 \%$. Skor tersebut masuk ke dalam kategori kuat. Hal ini menggambarkan bahwa sistem anggaran sudah bersifat terbuka. Keterbukaan anggaran ini meliputi penganggaran yang diketahui dengan baik oleh setiap personil. Selain itu pelaksanaan anggaran juga sesuai dengan peraturan perundangan yang berlaku termasuk dalam hal keterbukaan kepada publik di mana pelaksanaan anggaran selalu dilaporkan kepada publik.

Keempat yaitu adanya lembaga independen yang mengawasi jalannya pemerintahan. Pemerintah Provinsi Jawa Barat memiliki lembaga independen yang berfungsi mengawasi jalannya pemerintahan. Lembaga tersebut yaitu DPRD, Bawasda, dan BPK. Berdasarkan hasil jawaban responden didapat skor $72,0 \%$, berada pada tingkat kategori kuat. Dengan demikian, maka keberadaan lembaga tersebut sudah melaksanakan tugasnya sebagai pengawas dengan baik.

\section{Simpulan}

1. Penerapan Akuntansi Keuangan Daerah pada Pemerintah Provinsi Jawa Barat berada dalam rentang kategori sangat baik. Hal ini terbukti dengan diperolehnya skor dari responden berupa persentase sebesar $83,28 \%$ yaitu termasuk rentang kategori sangat baik.

2. Transparansi dan Akuntabilitas Laporan Keuangan Pemerintah Provinsi Jawa Barat berada dalam rentang kategori baik. Hal ini terbukti dengan diperolehnya skor dari responden berupa persentase sebesar 75,38\%.

3. Penerapan Akuntansi Keuangan Daerah (AKD) yang diterapkan oleh Pemerintah Provinsi Jawa Barat sangat baik. Hal ini terbukti berdasarkan hasil perhitungan, penilaian responden terhadap Akuntansi Keuangan Daerah pada Biro Keuangan SETDA Provinsi Jawa Barat nilai yang diperoleh adalah sebesar 83,28\% yang termasuk ke dalam kategori sangat baik. Maka hal ini akan sesuai dan berbanding lurus dengan baiknya Tingkat Transparansi dan Akuntabilitas Laporan Keuangan Pemerintah Provinsi Jawa Barat yang berada pada rentang kategori baik. Hal ini terbukti dengan diperolehnya skor dari responden berupa persentase sebesar 75,38\%. Maka Transparansi dan Akuntabilitas Laporan Keuangan Pemerintah Provinsi Jawa Barat tersebut termasuk dalam kriteria kuat yaitu berkisar antara $61 \%-80 \%$.

\section{Saran}

1. Sebaiknya Pemerintah Provinsi Jawa Barat lebih memberikan kemudahan bagi masyarakat yang ingin mengakses atau membutuhkan data keuangan seperti laporan keuangan ataupun data-data lainnya. Dengan lebih serius lagi mengelola website milik Pemprov Jabar sehingga semua data laporan keuangan bisa dimasukan ke dalam website tersebut.

2. Berkaitan dengan ketepatan waktu dalam penyusunan laporan ataupun penyajian laporan, ternyata persentase yang didapat dari jawaban responden cukup rendah di bawah $70 \%$. Disini dapat dilihat bahwa sering ada keterlambatan dalam penyusunan laporan. Oleh karena itu Pemerintahan Provinsi Jawa Barat diharapkan kedepannya untuk lebih meningkatkan dan memperhatikan ketepatan waktu dalam penyusunan dan penyajian laporan.

3. Dalam pelaksanaan transparansi dan akuntabilitas diperlukan adanya peningkatan dalam segi pemakaian media publikasi. Media yang digunakan selama ini masih kurang dan hanya sebatas pada media-media tertentu saja, yang tentu masih dirasa sangat kurang untuk memberikan informasi yang jelas dan terbaru. Informasi yang tersaji hendaknya meliputi semua aktifitas instansi mulai dari profil sampai dengan 
laporan keuangannya minimal setahun sekali pada media cetak seperti surat kabar, dan laporan pertanggungjawaban pelaksanaan atas anggaran yang telah ditetapkan.

\section{Daftar Pustaka}

Abdul Halim. (2001). Bunga Rampai Manajemen Keuangan Daerah. Yogjakarta: UPP AMP YKPN.

Abdul Halim. (2007). Akuntansi Sektor Publik: Akuntansi Keuangan Daerah. Jakarta: Salemba Empat.

Alamsyah. (1997). "Mekanisme Pengawasan APBD di Kabupaten Sleman". Tesis. Yogyakarta: MAP Universitas Gajah Mada.

Erwin, Gunawan. (2007). "Penerapan SAP No. 02 Laporan Realisasi Anggaran Dalam Mewujudkan Akuntabilitas dan Transparansi Pengelolaan Keuangan Daerah. Skripsi. Bandung : Fakultas Pendidikan Ilmu Pengetahuan Sosial Universitas Pendidikan Indonesia.

Iman, Bastari. (2004). Makalah Penerapan Sistem Akuntansi Keuangan Daerah dan Standar Akuntansi Pemerintah sebagai Wujud Reformasi Manajemen Keuangan Daerah. Juli. Jakarta.

Mardiasmo. (2004). “Otonomi dan Manajemen Keuangan Daerah”. Yogyakarta : Andi.

Nurlan, Darise. (2007). Pengelolaan Keuangan pada SKPD. Jakarta : Indeks.

Laporan Pemeriksaan Keuangan BPK RI Perwakilan Jawa Barat mengenai Laporan Keuangan Pemerintah Daerah Provinsi Jawa Barat Tahun Anggaran 2007.

PP Nomor 24 Tahun 2005 tentang Standar Akuntansi Pemerintahan (SAP).

Permendagri Nomor 13 Tahun 2006 tentang Pedoman Pengelolaan Keuangan Daerah.

Permendagri Nomor 59 Tahun 2007 tentang Perubahan atas Permendagri Nomor 13 Tahun 2006 tentang Pedoman Pengelolaan Keuangan Daerah.

Riduwan dan Akdon. (2007). Rumus dan Data dalam Aplikasi Statistika untuk Penelitian. Bandung : Alfabeta.

Tanjung, Abdul Hafiz (2008). Akuntansi Pemerintahan Daerah. Bandung: Alfabeta. 